Article

\title{
Reassessment of Long-Term Tsunami Hazards in Samoa Based on Sedimentary Signatures
}

\author{
Shaun Williams ${ }^{1, *} \oplus$, Ausetalia Titimaea ${ }^{2}$, Cyprien Bosserelle ${ }^{1} \oplus$, Lameko Simanu $^{3}$ and \\ Gegar Prasetya ${ }^{4}$ \\ 1 National Institute of Water and Atmospheric Research (NIWA), 10 Kyle Street, Riccarton, \\ Christchurch 8011, New Zealand; cyprien.bosserelle@niwa.co.nz \\ 2 Meteorology Division, Ministry of Natural Resources and Environment, Apia WS1338, Samoa; \\ goodsm10@gmail.com \\ 3 Disaster Management Division, Ministry of Natural Resources and Environment, Apia WS1339, Samoa; \\ lameko.simanu@mnre.gov.ws \\ 4 Indonesian Tsunami Scientific Community (IATsI), Jakarta 10110, Indonesia; gegar.prasetya@gmail.com \\ * Correspondence: shaun.williams@niwa.co.nz
}

Received: 30 September 2020; Accepted: 23 November 2020; Published: 27 November 2020

\begin{abstract}
Investigating tsunamis and cyclones from depositional records enables an understanding of the long-term hazards to coastal communities. In Samoa, whilst a long-term record of tsunamis and cyclones spanning the last few millennia has been previously suggested based on preliminary sediment core/trench studies, a detailed assessment of the characteristics distinguishing these events has not been presented. This study reevaluates the depositional evidence available for Samoa and offers a more robust interpretation of the temporal and spatial records of tsunami events preserved in the Samoan sedimentary record. Tsunami inundation and runup records of the 2009 South Pacific tsunami along with differences in depositional settings, and sedimentary and geochemical characteristics of the associated deposits provide modern analogies for interpreting comparable older event-type deposits deeper in the Samoan geological record. These are aided by the 1990/1991 Cyclones Ofa and Val deposits previously suggested at some sites, which provides a modern analogy for interpreting cyclone-related deposits. Available radiocarbon and radiometric dates for the core/trench sites provide time-indicators to identify contemporaneous events, which we use to interpret the long-term record of tsunamis in this island region.
\end{abstract}

Keywords: paleotsunamis; paleocyclones; inundation; sedimentary deposits; geochemical proxies; geochronological indicators

\section{Introduction}

Assessing the long-term inundation hazard of exposed coastal cities, communities, and infrastructure to tsunamis and cyclones requires a solid understanding of the timing and distribution of past events. Typically, this depends on an evaluation of the processes involved in the formation of tsunami and cyclone deposits both onshore and offshore, and their identification and distinction within the geologic record [1-4].

Whilst several studies have proposed the use of indicators such as deposit thickness [5], sedimentological properties [6], or geochemical proxies [7-9] to differentiate between onshore tsunami and cyclone deposits, the differences in characteristics using these criteria can be ambiguous [10-12]. The distance of a deposit inland from the shore can be an adequate indicator to preclude a cyclone deposit. Typically, however, geochronological indicators are used to provide a robust means to distinguish between tsunami and cyclone deposits [6], as these provide time-markers to differentiate 
deposits associated with a particular event. Corroboration with a known (pre-) historical tsunami or cyclone enables a more definitive assessment of whether an identified high-energy marine inundation (HEMI) deposit was left behind by a tsunami or a cyclone. However, this approach relies on the existence and availability of long-term documented or oral records of tsunamis and cyclones. For the case of Samoa, such records are limited, with formal written historical records only extending back to 1830 [13].

\subsection{The 2009 South Pacific Tsunami (SPT)}

Post-event studies following the devastating 2009 South Pacific Tsunami (SPT) in Samoa provided the opportunity to understand inundation and subsequent deposit characteristics of tsunamis in these islands $[14,15]$. This tsunami was generated by an outer-rise earthquake which was accompanied by near-simultaneous rupture of the shallow interface along the northern terminus of the Tongan Trench [16,17] (Figure 1). Local wave amplification on the nearby Tutuila Island in American Samoa was found to have resulted from trapping of waves within the foreshore (i.e., between coral reefs and shore) as well as in narrow embayments [18]. This significantly influenced the variability of tsunami impacts along the coast.

\subsection{Tsunami Deposit Studies Following the 2009 South Pacific Tsunami}

Prior to 2009, tsunami studies in Samoa were very limited and centred on warnings and emergency response [19]. Following the 2009 SPT, studies of marine deposits from historical and prehistorical flood events have been underway to quantify the long-term tsunami hazards for Samoa. Onshore inundation of the 2009 event resulted in preservation of distinct sedimentary and geochemical signatures in coastal wetlands at some of the impacted locations on Upolu and Savai'i islands [14,20,21]. A geochemical (elemental) signature of the event was preserved in two locations in which a deposit was not visibly discernible to the naked eye [22].

This study reevaluates the depositional records for tsunamis in Samoa by examining the characteristics (e.g., loss on ignition, grain size, geochemistry, geochronology, and context) used to interpret deposits of a tsunami origin [21,22]. The 2009 SPT and cyclone analogues (e.g., 1990/1991 Cyclones Ofa and Val) help in distinguishing tsunami from cyclone events in the depositional records. In addition, observed inundation and runup of the 2009 SPT as well as geomorphological characteristics of the depositional settings aid in interpreting events of a specific origin. A reinterpreted long-term history of tsunamis and cyclone events in this region based on depositional records is discussed. 

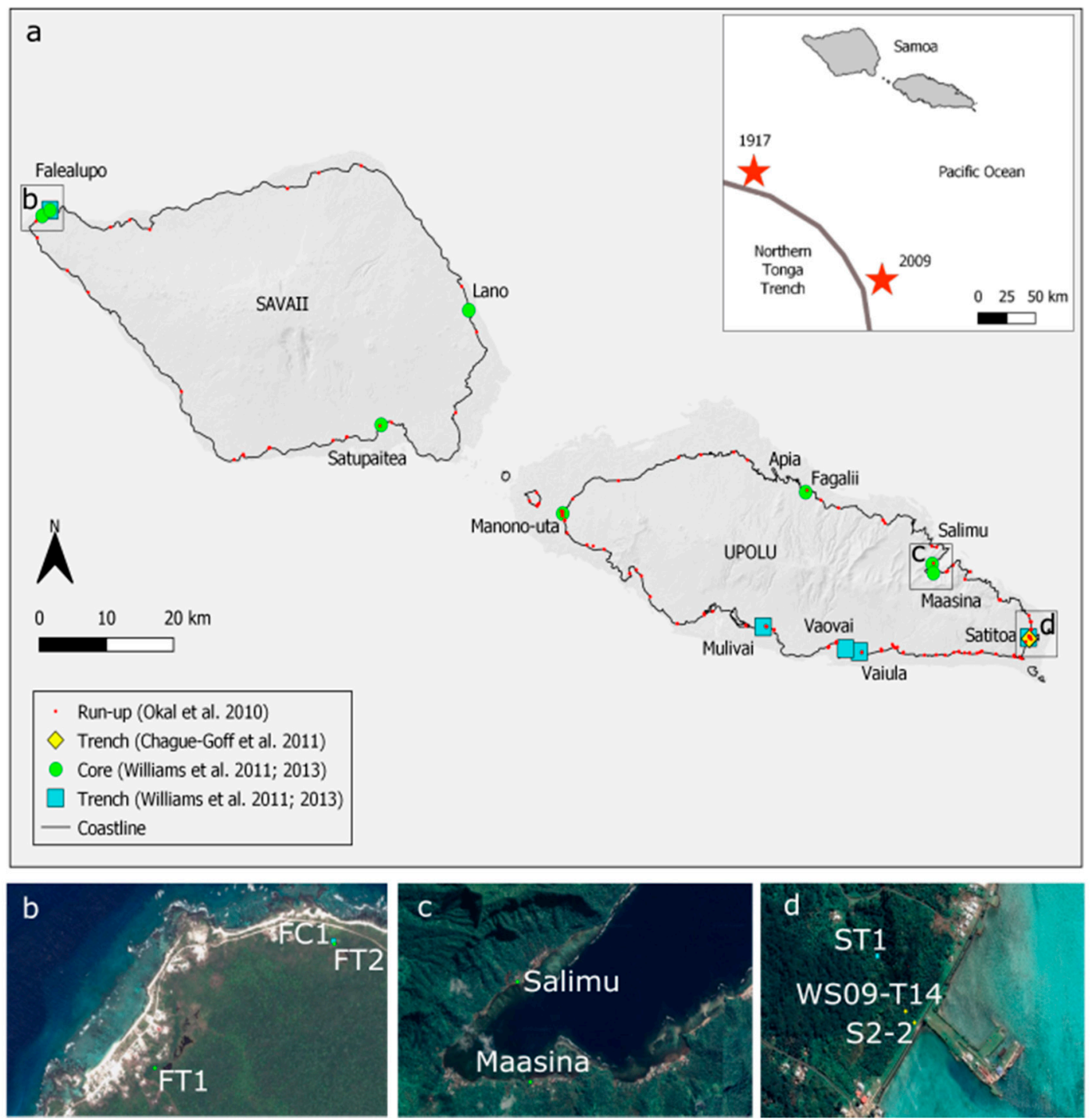

Figure 1. (a) Regional setting of Samoa showing the two main islands Upolu and Savaii showing surveyed run-up locations of the 2009 South Pacific Tsunami (SPT) in [13], sediment trench location in [14], and sediment core and trench sites in [20,21]. Inset shows the location of Samoa relative to the Northern Tonga Subduction Arc (NTSA) at the Northern Tonga Trench boundary with the stars indicating the locations of the 2009 and 1917 earthquake epicentres. (b) Locations of core sites at Falealupo [21]. (c) Locations of core sites at Maasina and Salimu [21]. (d) Location of trench sites S2-2 and WS09-T14 in [14] as well as ST1 in [20] at Satitoa.

\section{Review of Available Data}

Sites investigated by $[20,21]$ are listed in Table 1 , with their selection based on their potential to preserve marine deposits even though some of them were at considerable distance from the shore. Their elevations of $5 \mathrm{~m}$ or above incidentally screen out minor cyclone events or far-field tsunamis from the Pacific Rim. The locations of excavated sites that contained 2009 SPT deposits as well as sites that did not but contained potential historical or paleo-tsunami and/or cyclone deposits are shown in Figure 2. Trench excavations and coring using a D-Corer took place in 2010, with the collected samples providing the basis for sedimentological, geochemical, and geochronological analysis. The dataset covers approximately 3000 years of geological records of flood events from tsunamis and/or cyclones. 


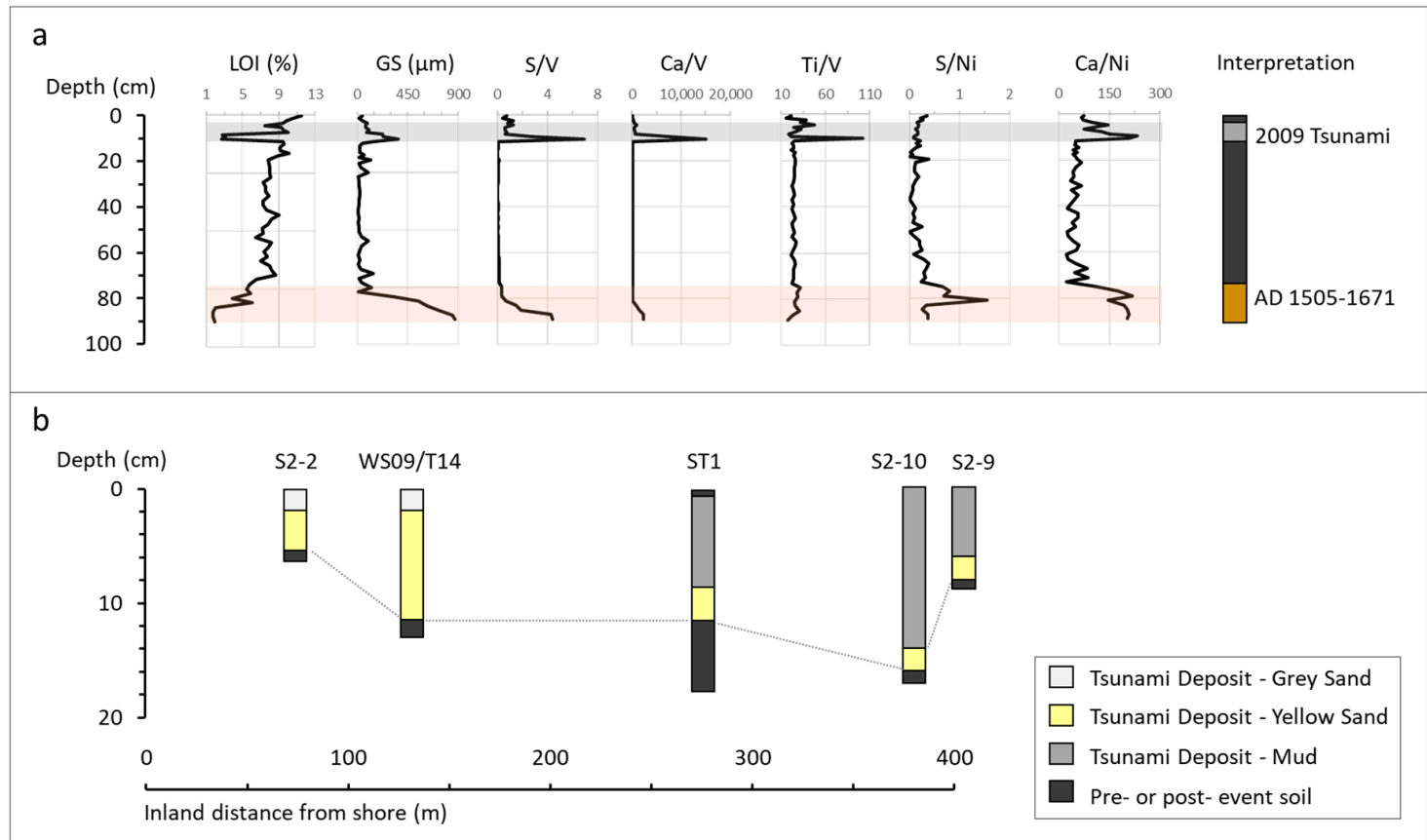

Figure 2. (a) Loss on Ignition (LOI), grain size (GS), and elemental proxies for the core sampled from Satitoa: clear signals of the 2009 SPT are observed at approximately $12 \mathrm{~cm}$ core depth. Comparable signals are also observed for a unit at approximately $82 \mathrm{~cm}$, although inconsistencies between the Ti and S patterns between this unit and the 2009 SPT at the surface suggests a different type of coastal process or event origin. (b) Comparison of the inland extent of the 2009 SPT at Satitoa using available sedimentary data: Samples S2-2, WS09/T14, S2-9, and S2-10 shown were derived from [14]. Sample ST-1 was derived from [21] and is discussed in this study.

Table 1. Sites investigated in this study: all sites were located in wetland environments. The inland distance and elevation were updated in this assessment using Light Detection and Ranging (LiDAR) data [23]. Physical attributes of the 2009 South Pacific Tsunami (SPT) deposit refer to empirical field observations at each site.

\begin{tabular}{|c|c|c|c|c|c|}
\hline Site & Location & $\begin{array}{c}\text { Inland } \\
\text { Distance }\end{array}$ & Elev. & Sample Resolution & $\begin{array}{l}\text { Physical Attributes of the } 2009 \\
\text { SPT Deposit }\end{array}$ \\
\hline Satitoa, Upolu & $\begin{array}{l}14^{\circ} 01.363^{\prime} \mathrm{S} \\
171^{\circ} 25.754^{\prime} \mathrm{W}\end{array}$ & $280 \mathrm{~m}$ & $1.1 \mathrm{~m}$ & $\begin{array}{l}1 \mathrm{~cm}(\text { up to } 20 \mathrm{~cm}) \\
2 \mathrm{~cm}(20-90 \mathrm{~cm})\end{array}$ & $\begin{array}{c}2-3 \mathrm{~cm} \text { thick grey-yellow sand at } \\
\text { base overlain by } 3-5 \mathrm{~cm} \text { thick dark } \\
\text { brown silty clay, with } 2-3 \mathrm{~cm} \\
\text { muddy silt cap at surface }\end{array}$ \\
\hline Mulivai, Upolu & $\begin{array}{l}14^{\circ} 00.505^{\prime} \mathrm{S} ; \\
171^{\circ} 47.651^{\prime} \mathrm{W}\end{array}$ & $68 \mathrm{~m}$ & $1.6 \mathrm{~m}$ & Varied/Inconsistent & $\begin{array}{l}11 \mathrm{~cm} \text { thick grey-brown sand, fining } \\
\text { upwards (coarse to medium) }\end{array}$ \\
\hline Vaovai, Upolu & $\begin{array}{l}14^{\circ} 02.140^{\prime} \mathrm{S} ; \\
171^{\circ} 40.832^{\prime} \mathrm{W}\end{array}$ & $25 \mathrm{~m}$ & $1.1 \mathrm{~m}$ & $2 \mathrm{~cm}$ & $\begin{array}{l}1-2 \mathrm{~cm} \text { thick medium grey sand, } \\
\text { fining upwards }\end{array}$ \\
\hline Vaiula, Upolu & $\begin{array}{l}14^{\circ} 02.361^{\prime} \mathrm{S} ; \\
171^{\circ} 39.631^{\prime} \mathrm{W}\end{array}$ & $124 \mathrm{~m}$ & $2.1 \mathrm{~m}$ & Varied/Inconsistent & $1-2 \mathrm{~cm}$ thick medium grey sand \\
\hline $\begin{array}{l}\text { Ma'asina, } \\
\text { Upolu }\end{array}$ & $\begin{array}{l}13^{\circ} 56.607^{\prime} \mathrm{S} ; \\
171^{\circ} 33.585^{\prime} \mathrm{W}\end{array}$ & $32 \mathrm{~m}$ & $1.3 \mathrm{~m}$ & $0.5 \mathrm{~mm}$ (ITRAX) & None observed \\
\hline Salimu, Upolu & $\begin{array}{l}13^{\circ} 55.904^{\prime} \mathrm{S} \\
171^{\circ} 33.614^{\prime} \mathrm{W}\end{array}$ & $20 \mathrm{~m}$ & $2.4 \mathrm{~m}$ & $4 \mathrm{~cm}$ & None observed \\
\hline Fagali'i, Upolu & $\begin{array}{r}13^{\circ} 50.628^{\prime} \mathrm{S} ; \\
171^{\circ} 44.131^{\prime} \mathrm{W}\end{array}$ & $180 \mathrm{~m}$ & $1.5 \mathrm{~m}$ & $4 \mathrm{~cm}$ & None observed \\
\hline $\begin{array}{l}\text { Manono-uta, } \\
\text { Upolu }\end{array}$ & $\begin{array}{l}13^{\circ} 52.120^{\prime} \mathrm{S} \\
172^{\circ} 04.263^{\prime} \mathrm{W}\end{array}$ & $115 \mathrm{~m}$ & $1.3 \mathrm{~m}$ & $4 \mathrm{~cm}$ & None observed \\
\hline
\end{tabular}


Table 1. Cont.

\begin{tabular}{|c|c|c|c|c|c|}
\hline Site & Location & $\begin{array}{c}\text { Inland } \\
\text { Distance }\end{array}$ & Elev. & Sample Resolution & $\begin{array}{c}\text { Physical Attributes of the } 2009 \\
\text { SPT Deposit }\end{array}$ \\
\hline $\begin{array}{l}\text { Falealupo } \\
\text { (FT1), Savaii }\end{array}$ & $\begin{array}{c}13^{\circ} 30.064^{\prime} \mathrm{S} \\
172^{\circ} 47.161^{\prime} \mathrm{W}\end{array}$ & $284 \mathrm{~m}$ & $1.2 \mathrm{~m}$ & $1 \mathrm{~cm}$ & None observed \\
\hline $\begin{array}{l}\text { Falealupo } \\
\text { (FC1), Savaii }\end{array}$ & $\begin{array}{c}13^{\circ} 29.663^{\prime} \mathrm{S} \\
172^{\circ} 46.523^{\prime} \mathrm{W}\end{array}$ & $138 \mathrm{~m}$ & $0.5 \mathrm{~m}$ & $5 \mathrm{~cm}$ & None observed \\
\hline $\begin{array}{l}\text { Falealupo } \\
\text { (FT2), Savaii }\end{array}$ & $\begin{array}{c}13^{\circ} 29.670^{\prime} \mathrm{S} \\
172^{\circ} 46.521^{\prime} \mathrm{W}\end{array}$ & $152 \mathrm{~m}$ & $0.5 \mathrm{~m}$ & $\begin{array}{l}\text { Varied/Inconsistent } \\
\qquad(2-5 \mathrm{~cm})\end{array}$ & None observed \\
\hline Lano, Savaii & $\begin{array}{c}13^{\circ} 37.176^{\prime} \mathrm{S} ; \\
172^{\circ} 11.938^{\prime} \mathrm{W}\end{array}$ & $116 \mathrm{~m}$ & $1.4 \mathrm{~m}$ & $\begin{array}{c}4 \mathrm{~cm} \text { (GS, LOI); } 0.5 \mathrm{~mm} \\
\text { (ITRAX) }\end{array}$ & None observed \\
\hline $\begin{array}{l}\text { Satupaitea, } \\
\text { Savaii }\end{array}$ & $\begin{array}{c}13^{\circ} 45.576^{\prime} \mathrm{S} \\
172^{\circ} 19.209^{\prime} \mathrm{W}\end{array}$ & $85 \mathrm{~m}$ & $1.4 \mathrm{~m}$ & $3 \mathrm{~cm}$ & None observed \\
\hline
\end{tabular}

Key aspects of previous investigations are summarized below:

- Field investigations were carried out in July and August 2010 at selected coastal sites in Upolu and Savaii. Trench and coring via excavator and D-corer were used to obtain samples for laboratory analysis [19]. Proxy criteria used for identifying high-energy marine inundation deposits (HEMIs) in the Samoan geologic record were based on analogue deposits associated with the 2009 SPT described by $[14,15,20,21]$. Preliminary stratigraphic logging was carried out at the investigated trench sites, while the sampled cores were logged at the University of Canterbury, New Zealand [21]. All trench and core samples were obtained from coastal wetland environments.

- Sedimentological analysis incorporating loss on ignition (LOI) was carried out at the University of Canterbury following the methods described by [14]. Grain size analysis was carried out via laser diffraction using the Horiba Particle Analyzer at the University of Canterbury, adapting the methods presented in [24]. The geochemical composition of most sedimentary sequences was determined using a portable X-ray fluorescence spectrometer (pXRF) at the University of Canterbury [20]. In the cases of Ma'asina, Manono, and Lano sites, elemental profiles were obtained using the ITRAX core scanner at the Institute for Environmental Research, Australian Nuclear Science and Technology Organisation (ANSTO) [22].

- Radiocarbon dating of organic paleosols, plant fragments, and carbonate shells associated with likely HEMI deposits was conducted at the Radiocarbon Dating Laboratory of the University of Waikato (WK-sample code) and at ANSTO's Accelerator Mass Spectrometry Laboratory (OZP-sample code) (Table A1). Radiometric dating $\left({ }^{210} \mathrm{~Pb}\right)$ was carried out on samples from Falealupo (Table A2) and Ma' asina (Table A3) using alpha spectrometry at ANSTO's Environmental Radioactivity Measurement Centre [22]. Ages presented for these sites were calculated using the CRS (constant rate of ${ }^{210} \mathrm{~Pb}$ supply) and CIC (constant initial ${ }^{210} \mathrm{~Pb}$ concentration) models following the methods in [25]. In this study, the unsupported ${ }^{210} \mathrm{~Pb}$ activities for the Falealupo core exhibited a decay profile with depth, suggesting a constant rate of ${ }^{210} \mathrm{~Pb}$ supply, and hence the CRS model is preferred as more robust time-marker at this site. In contrast, the unsupported ${ }^{210} \mathrm{~Pb}$ activities at Ma'asina exhibit a step in the decay profile with depth, which indicates a change in sedimentation/deposition. This implies an initial unsupported ${ }^{210} \mathrm{~Pb}$ concentration in sediments at this site at the time of initial deposition; thus, we prefer the CIC model time-marker at Ma'asina.

For this study, we use the characteristic comparation of an identified HEMI deposit with the 2009 SPT deposit as well as inland distance from the shore as benchmarks to preclude a cyclone origin. While the paleontological characteristics of the 2009 SPT were studied at Satitoa [14] (Figure 2), the absence of detailed paleontological studies at site-specific locations limits the interpretations in this study to the available sedimentological, geochemical, and geochronological proxies shown in Table 2. Simple stratigraphy depth interpolation and cross-site comparisons are used to estimate the contemporaneity and probable ages of HEMIs at sites containing limited or no geochronological reference ages. 
Table 2. Comparison of available evidence for each site discussed in this study: shaded cells indicate the availability of proxy data for the site.

\begin{tabular}{|c|c|c|c|c|c|c|}
\hline \multirow{2}{*}{ Site } & \multirow{2}{*}{$\begin{array}{l}\text { GS } \\
(\mu \mathrm{m})\end{array}$} & \multirow{2}{*}{$\begin{array}{c}\operatorname{LOI}_{\left(5500^{\circ}\right)} \\
(\%)\end{array}$} & \multicolumn{2}{|c|}{ Geochemistry $(\mu \mathrm{m})$} & \multirow{2}{*}{ Geochronology } & \multirow{2}{*}{$\begin{array}{l}\text { Observed in } \\
\text { Stratigraphy }\end{array}$} \\
\hline & & & pXRF & ITRAX & & \\
\hline Satitoa, Upolu & $\checkmark$ & $\checkmark$ & $\checkmark$ & $\times$ & $\checkmark$ & $\checkmark$ \\
\hline Mulivai, Upolu & $\checkmark$ & $\checkmark$ & $\checkmark$ & $\times$ & $\checkmark$ & $\checkmark$ \\
\hline Vaovai, Upolu & $\checkmark$ & $\checkmark$ & $\checkmark$ & $x$ & $\checkmark$ & $x$ \\
\hline Vaiula, Upolu & $x$ & $x$ & $\checkmark$ & $x$ & $x$ & $\checkmark$ \\
\hline Ma'asina, Upolu & $\checkmark$ & $\checkmark$ & $x$ & $\checkmark$ & $\checkmark$ & $\checkmark$ \\
\hline Fagali'i, Upolu & $\checkmark$ & $\checkmark$ & $\checkmark$ & $\times$ & $\checkmark$ & $x$ \\
\hline Manono-uta, Upolu & $\checkmark$ & $\checkmark$ & $x$ & $\checkmark$ & $x$ & $x$ \\
\hline $\begin{array}{c}\text { Falealupo (FT1), } \\
\text { Savaii }\end{array}$ & $x$ & $x$ & $\checkmark$ & $x$ & $\times$ & $x$ \\
\hline $\begin{array}{l}\text { Falealupo (FC1), } \\
\text { Savaii }\end{array}$ & $\checkmark$ & $\checkmark$ & $\checkmark$ & $x$ & $\checkmark$ & $\checkmark$ \\
\hline $\begin{array}{l}\text { Falealupo (FT2), } \\
\text { Savaii }\end{array}$ & $x$ & $x$ & $\checkmark$ & $x$ & $\times$ & $x$ \\
\hline $\begin{array}{l}\text { Lano, } \\
\text { Savaii }\end{array}$ & $\checkmark$ & $\checkmark$ & $x$ & $\checkmark$ & $\checkmark$ & $x$ \\
\hline Satupaitea, Savaii & $\checkmark$ & $\checkmark$ & $\checkmark$ & $\times$ & $x$ & $\checkmark$ \\
\hline
\end{tabular}

\section{Interpretation of Depositional Evidence}

\subsection{The 2009 SPT Deposit Analogue}

The available datasets in [26] indicate that the 13-cm thick 2009 SPT deposit at Satitoa formed the surface layer of the trench profile located $280 \mathrm{~m}$ inland from the high-tide mark. The 2009 SPT unit fines upwards to a grain size similar to that of the pre-event soil (Figure 2). A marked decrease in LOI (\% organic material in the sediment) (1\%) also occurs in the 2009 SPT deposit immediately above the lower contact with the pre-event soil. LOI concentrations generally increase upwards to levels higher than those in the underlying soil. A concurrent maximum peak in all of the detected elements $(\mathrm{S}, \mathrm{Ca}$, $\mathrm{Ti}, \mathrm{Cr}, \mathrm{Mn}, \mathrm{Fe}, \mathrm{Ni}$, and $\mathrm{Sr}$ ) when normalized to vanadium (V) is observed near the base of the deposit, with a marked decrease immediately above, returning to levels similar to that of the pre-event soil. $\mathrm{V}$ is a relatively abundant trace element in both terrestrial and marine environments [27] and was not a target element for comparison in this study. It was thus suited for normalizing targeted elements against in this analysis to enable consistent comparison of the relative quantities of predominantly marine-derived target elements (e.g., $\mathrm{Ca}$ and $\mathrm{Sr}$ ) and predominantly terrestrial-derived target elements (e.g., $\mathrm{Ti}, \mathrm{Fe}, \mathrm{Ni}$, etc). $\mathrm{Ca}$ and $\mathrm{Sr}$ reflect the occurrence of coral reef material that constitutes the deposit, while $\mathrm{Fe}, \mathrm{Mn}, \mathrm{Ti}, \mathrm{Cr}$, and $\mathrm{Ni}$ reflect terrestrially derived soils. The decrease in elemental concentrations towards the surface reflects ponding and settling of finer-grained, reworked, and mixed sediment to form a mud cap after the tsunami waned.

These observations are consistent with the sedimentary and geochemical characteristics of the deposit at Satitoa presented in [14]. Deposits less than $150 \mathrm{~m}$ inland were predominantly made up of thick calcareous yellow sands overlain by finer grey sands compared with deposits more than $200 \mathrm{~m}$ inland, which comprised thinner sand layers overlain by thicker and finer mud deposits (Figure 2). The overall thickening of the tsunami mud layer between 200 and $400 \mathrm{~m}$ inland reflects reworking and deposition of preexisting surface soil/mud into the topographically lower wetland. In contrast, the overall inland thinning of the sand layer reflects settling of coarser sediment with inland tsunami energy loss.

Similar proxy characteristics were exhibited by a unit with an upper contact at $82 \mathrm{~cm}$ depth in the Satitoa core. This unit had similar sedimentary and geochemical trends to the 2009 SPT; however, the complete deposit was not captured in the core, thus making it difficult to adequately compare 
its characteristics with the 2009 tsunami deposit. Radiocarbon dating of a sample (Wk30079) taken from the overlying soil layer at $81 \mathrm{~cm}$ depth yielded an age of $0-290 \mathrm{cal} \mathrm{BP}((68.2 \%$ prob.) (AD $1805 \pm$ 145)) (Table A1). The ${ }^{14} \mathrm{C}$ age of an unidentified shell sample (OZP119) associated with the deposit at approximately $82 \mathrm{~cm}$ depth yielded an age of $307-403 \mathrm{cal} \mathrm{BP}((68 \%$ prob.) (AD $1595 \pm 48)$ ). The age for the overlying soil implies a minimum age for this event of approximately AD $1805 \pm 145$. The age of the shell sample obtained from within the deposit itself represents either 1) a maximum age for the event which formed the deposit around AD $1595 \pm 48$ or 2) the shell having possibly been reworked during deposition and being possibly older than the event itself, implying a potential event-occurrence between AD $1595 \pm 48$ to AD $1805 \pm 145$. Compared with the 2009 SPT elemental signals at the surface of the core, the unit at approximately $82 \mathrm{~cm}$ exhibits an elevated $\mathrm{S}$ signal as shown through the $\mathrm{S} / \mathrm{Ni}$ ratio (Figure 2). Similarly, the Ti/V ratio for the unit at $82 \mathrm{~cm}$ does not exhibit the same pattern as the 2009 SPT at the surface. These patterns are not observed for any of the other elements, which suggests that the unit could represent a different type of process other than a tsunami (e.g., paleo- beach, coast, or brackish environment).

The 2009 SPT deposit also formed the surface layers of the trench profiles at Vaovai and Vaiula [21], with its elemental signature noted at the surfaces of the core profiles at Satupaitea (pXRF data) and Manono (ITRAX data) [22]. While similar field descriptions and proxy characteristics are reported for the surface 2009 SPT deposits at Mulivai and Vaiula [19], the sampling resolution at these sites were too coarse to provide meaningful proxy relationships. However, the coarse trends and availability of geochronological time-markers at Mulivai do provide useful indicators for assessing the regional distribution of contemporaneous deposits between different sites.

Notwithstanding, deposit characteristics at Vaovai, Satupaitea, and Manono, however, are not as distinct as those at Satitoa, which suggests (1) partial or truncated deposits at these sites due to post-event processes, (2) local geomorphologic controls influencing deposition, and/or (3) inconsistencies in data resolution. Nevertheless, similar HEMI trends to those observed at Satitoa exist within their profiles, forming a basis for interpreting their likely origin and association. The 2009 SPT deposits at the sites described above provide analogues for the identification of similar older sedimentary units preserved in the trench/core data.

\subsection{Comparison with Other Depositional Analogues}

${ }^{210} \mathrm{~Pb}$ data obtained from FC1 at Falealupo on western Savaii provide geochronological evidence for the 1990/1991 Cyclones Ofa and/or Val (Figure 3). The elemental signatures for the identified cyclones show a slightly reverse trend within the HEMI deposit compared with the 2009 SPT at Satitoa, whereby an upwards increase in elemental compositions within the deposit is observed before returning to pre-event levels at the surface contact (Table 3). This probably reflects more poorly sorting of sediments during deposition. Interestingly, at FT1 located further south of FC1, a distinct signature directly comparable with the 2009 SPT elemental signature at Satitoa is observed between 20 and $30 \mathrm{~cm}$ depths, potentially representing the 1917 event which is thought to have inundated this site [21].

In Ma'asina on northwestern Upolu, the $\mathrm{Si} / \mathrm{Ti}$ proxy shows a HEMI deposit signature which is depth-associated with the ${ }^{210} \mathrm{~Pb}$ age of $1957 \pm 8$. A HEMI signature as used here refers to the characteristic "signal" of a deposit preserved in the landscape (e.g., sedimentary, geochemical, geochronological, etc). It is possible that the HEMI signature at Ma'asina represents the 1960 Chile Tsunami [22], which is known to have impacted this site [28]. However, the lack of similar signatures in other proxy data at this site prohibits a definite association. 


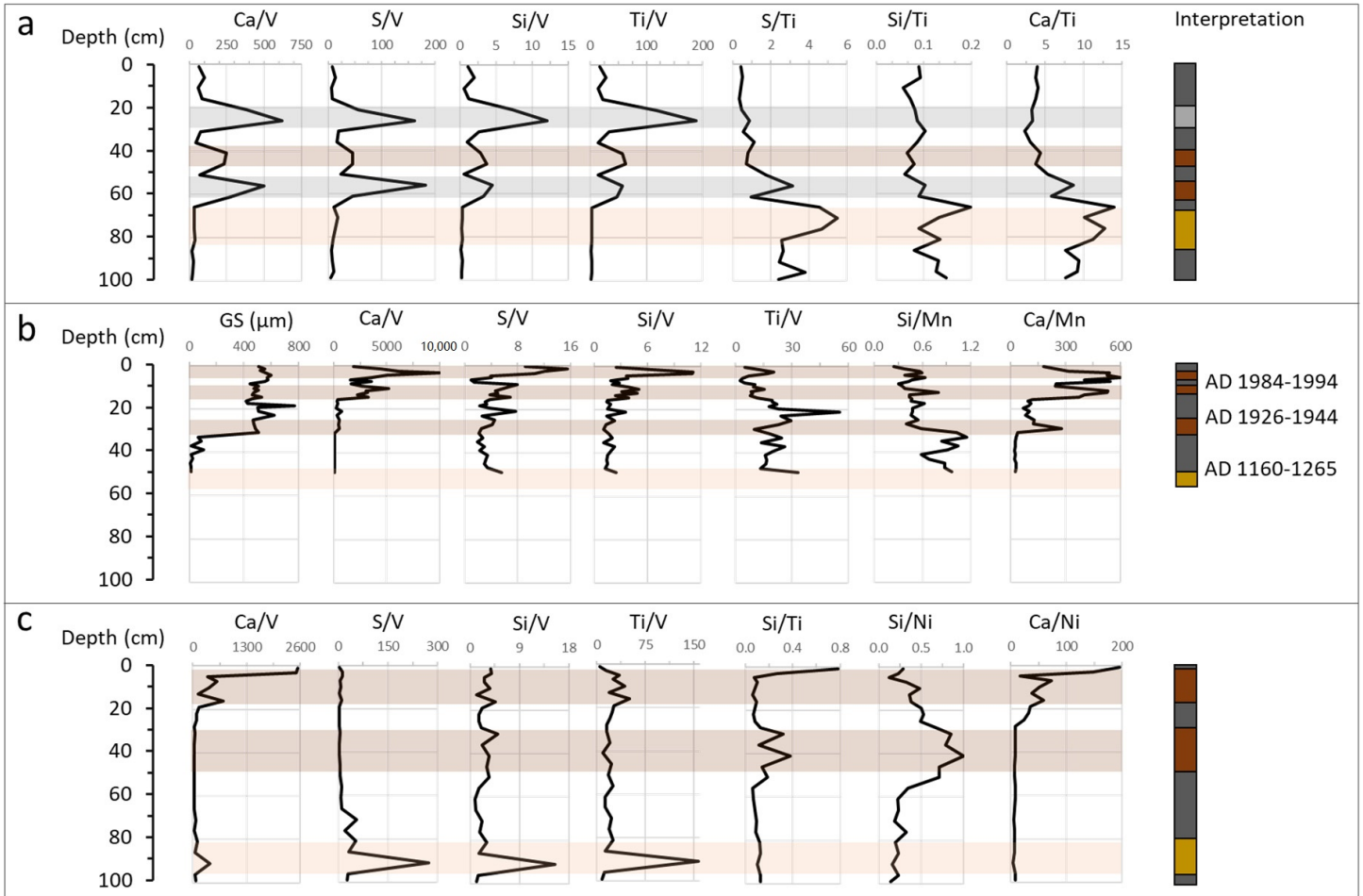

Figure 3. Cores sites available for Falealupo: (a) elemental proxies for the core sampled from site FT1. The location of this site at approximately $280 \mathrm{~m}$ inland of the coast and significant elemental concentration elevations when normalized against $V$ for the unit peak at $25 \mathrm{~cm}$ compared with other elemental pulses observed deeper in the profile suggests a potential tsunami origin. Based on its depth and historical records, it is possible that this unit represents the 1917 tsunami which is known to have impacted the village adjacent to this site. (b) Elemental proxies for the core sampled from site FC1: geochronological data available for this site suggest that the high-energy marine inundation (HEMI) deposit signals at the surface of the core probably represent storm and/or storm-derived sediment deposited by the 1990/1991 Tropical Cyclones Ofa and Val which severely impacted Falealupo. (c) Elemental proxies for the core sampled from site FT2: the absence of consistent compositions of S, Si, and $\mathrm{Ti}$ when normalized against $\mathrm{V}$ compared with the Ca provides a potential indicator for dismissing a tsunami origin for any of the HEMI deposits observed at this site. However, this observation is based on a comparison of limited and inconsistent datasets between two sites only and may not be representative of other sites (see Sections 4 and 5 for descriptions of the data limitations).

Geochronology indicators from FC1 at Falealupo suggests the preservation of complete deposit signatures associated with the 1990/1991 Cyclones Ofa and Val at this location (Figure 3). Regarding the 2009 SPT deposits preserved along investigated sites on southern Upolu, the site at Satitoa provides the most credible case of a complete deposit signature, with characteristics consistent with descriptions presented by [3]. This enables a comparative distinction to be made with the cyclone deposits at Falealupo.

Maximum modelled offshore wave heights of approximately $13 \mathrm{~m}$ (1990 Cyclone Ofa) and approximately $10 \mathrm{~m}$ (1991 Cyclone Val) at Falealupo (http://wacop.gsd.spc.int/SamoaMaxWaves.html) and along with the narrow reef-fringed shelf would have provided the necessary conditions conducive for significant cyclone-wave inundation. Nearshore mixing, transportation, and deposition of calcareous sands sourced from the nearshore give rise to the strong Ca signals observed.

In contrast, the $\mathrm{Ca} / \mathrm{V}$ ratio and LOI trends of the 2009 SPT HEMI at Satitoa suggest an opposite trend to the cyclone deposits at Falealupo. That is, the Ca composition decreases upwards within the HEMI and the LOI increases upwards. These differences, albeit subtle, likely reflect different depositional processes in a cyclone as opposed to a tsunami and provide a means to distinguish 
identified palaeo-HEMI deposits as being of probable tsunami or cyclone in origin. Interestingly, the S, Si, and Ti signals at site FT2 (located near site FC1; see Figure 1 at Falealupo provide key signs which help to distinguish tsunami elemental signals from other HEMIs. The absence of consistent compositions of $\mathrm{S}, \mathrm{Si}$, and $\mathrm{T}$ when normalized against $\mathrm{V}$ compared with the Ca signal provides a potential indicator for dismissing a tsunami origin for any of the HEMI signals observed at site FT1 (Figure 3). That is, clear discernible increases in the compositions of all detected elements were observed in the 2009 SPT signals at Satitoa when normalized against V (Figure 2). At FT1 (located southwest of sites FC1 and FT2), the consistency of elemental patterns when normalized against V provides a basis for inferring a potential tsunami origin for the unit at approximately $25 \mathrm{~cm}$. Based on its depth within the core and historical records, it is possible that this unit represents the 1917 tsunami which is known to have impacted the Falealupo area.

Table 3. General criteria for distinguishing tsunami and cyclone deposit signatures based on observations in this study.

\begin{tabular}{|c|c|c|}
\hline Proxy & Tsunami Signature & Cyclone Signature \\
\hline Grain size & $\begin{array}{l}\text { Marked coarsening in grain size relative to } \\
\text { pre-event soil, then a general upwards } \\
\text { fining to a grain size similar to pre-event soil }\end{array}$ & $\begin{array}{l}\text { Marked coarsening in grain size relative to } \\
\text { pre-event soil, then either an upwards } \\
\text { coarsening within the deposit or a non-uniform } \\
\text { chaotic trend, followed by a marked decrease to } \\
\text { a level similar to pre-event soil }\end{array}$ \\
\hline $\begin{array}{l}\text { Elemental ratios } \\
\text { (Geochemical) }\end{array}$ & $\begin{array}{l}\text { Marked increase in ratio compositions of all } \\
\text { elements relative to } \mathrm{V} \text { at the contact with } \\
\text { pre-event soil, then a marked upwards } \\
\text { decrease to pre-event composition levels at } \\
\text { the surface contact }\end{array}$ & $\begin{array}{l}\text { Marked increase in ratio compositions of all } \\
\text { elements relative to } \mathrm{V} \text { at the contact with } \\
\text { pre-event soil, then an upwards increase within } \\
\text { the deposit before returning to pre-event levels } \\
\text { at the surface contact }\end{array}$ \\
\hline
\end{tabular}

An interview with a Falealupo resident [21] provides a potential eye-witness account for this event which is associated with a life story told to her by her father who was born in 1886. According to the account, her father, when he was a young man, was returning home one day after working in their inland plantation when he witnessed a large wave sweep through their coastal property located approximately $180 \mathrm{~m}$ from the shore. While the exact year which this event occurred was not known by the interviewee, it is highly probable that the event described happened in the evening as inferred by her father witnessing the wave "after work". This timing corresponds with the 1917 earthquake-tsunami which occurred at approximately 6:50 p.m. (Samoan local time) and would suggest her father was about 31 years old if it was indeed the 1917 tsunami he had experienced. Given that this is the only known major sudden/rapid inundation event to have impacted Samoa between 1886 and 1918, we infer that the eye-witness account is describing the 1917 tsunami. This implies that the event likely inundated core site FT1, resulting in the elemental peaks observed at approximately $25 \mathrm{~cm}$. These observations along with the geochemical and geochronological evidence support the interpretation that this HEMI deposit is associated with the 1917 event.

In Ma'asina on northwestern Upolu, it has been suggested that the ${ }^{210} \mathrm{~Pb}$ age of $1957 \pm 8$ for elemental peaks at approximately $10 \mathrm{~cm}$ depth could be associated with the 1960 Chile Tsunami which is known to have impacted this area [12,28]. The absence of a Ca proxy signature for this HEMI deposit likely reflects a general Ca source-deficiency in the nearshore at Ma'asina.

Other sites on southern Upolu in which the 2009 SPT deposit was preserved (Vaovai, Mulivai, and Manono) do not give the same signature trends as those observed at Satitoa. These sites were closer to 
the coastline than the Satitoa site, and their 2009 SPT deposits may not have been well preserved. Thus, they may not reflect complete deposit signatures. Further detailed studies may reveal the presence of complete, well-reserved, signature deposits at these sites.

In general, the subtle differences between the signature trends for the cyclone HEMI deposits at Falealupo compared with the 2009 SPT at Satitoa enable distinctions to be made between probable cyclone and tsunami deposits in the Samoan geologic record. The variations in evidence between the Satitoa and Falealupo analogues likely reflect the differing nature of depositional and/or erosional processes during a tsunami compared with a cyclone. Furthermore, a distinct $S$ elemental peak is consistently observed at all the sites which does not correspond with the tsunami and cyclone sediment patterns at Satitoa and Falealupo, respectively, and likely represents an entirely different coastal process (e.g., paleo-beach, coast, and brackish environment associated with a recent sea-level high stand).

\subsection{Comparison and Application of Evidence}

Grain size and LOI results between different sites showed major inconsistencies in the trends, which probably reflects differences in site-specific offshore and nearshore sediment availability and geomorphologic configuration of depositional environments. On balance, we find that the geochemical (elemental) proxies along with geochronological reference ages provide more consistent controls for screening potential HEMI deposits compared with the grain size and LOI results.

Nevertheless, the general criteria used here for distinguishing between tsunami and cyclone deposit signatures are provided in Table 2 and are consolidated in Figure 4. Events identified deeper in the geologic record or those which could not be corroborated with historical information were classified based on some of the corresponding criteria being met for either process and do not consider signatures left by individual waves of an event or the erosional effects between waves. Comparisons between the HEMI deposits coupled with geomorphic and paleo-environmental understanding enables probable stratigraphic relationships to be established at sites containing HEMIs with unknown ages to sites with available geochronological data (Figure 4).

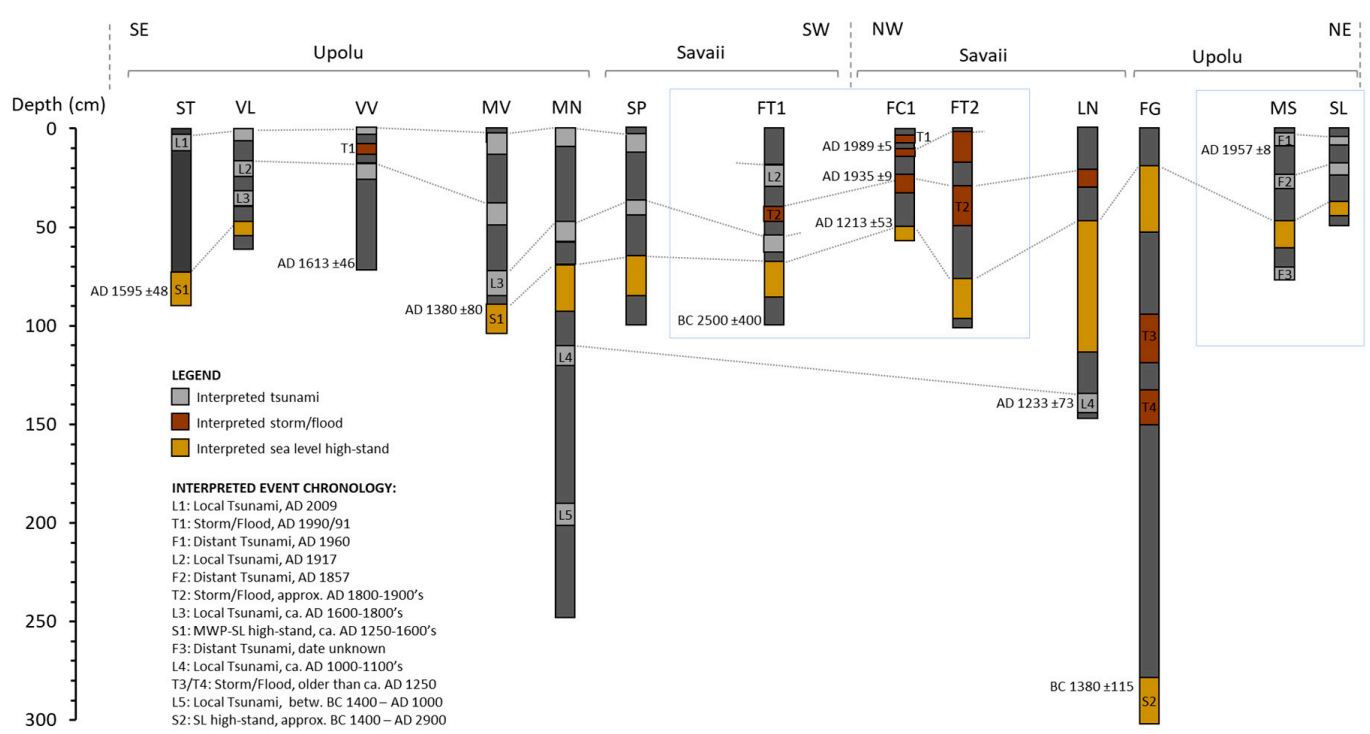

Figure 4. Contemporaneity between identified HEMIs at the investigated sites: the 2009 SPT deposits were confined to the southeast, south, and southwest shores of Upolu as well as southeast shores of Savaii. A distinct $S$ signal consistent across most sites is inferred using geochronological time-markers at Satitoa, Mulivai, Falealupo FC1, and Lano and is interpreted to represent the approximately AD 1000-1500 sea level high-stand to represent ST = Satotia; VL = Vaiula; VV = Vaovai; MV = Mulivai; MN = Manono; $\mathrm{SP}=$ Satupaitea; FT1 = Falealupo core site 1; FT2 = Falealupo core site 2; FC1 = Falealupo trench site. $\mathrm{LN}=$ Lano; FG = Fagalii; MS = Maasina; and SL = Salimu. Geochronological data shown are provided in Appendix A. 


\section{Interpretation of Tsunami Chronology}

The comparative assessment described above provides a basis for reinterpreting the tsunami history in Samoa based on sedimentary evidence. The spatial distribution of contemporaneous deposits around Upolu and Savaii islands helps to identify probable local events which are comparable with a 2009-type tsunami and associated source region.

The distribution of tsunami events inferred through contemporaneous deposits is shown in Figure 5. For the case of the 2009 event (Figure 5a), deposits were confined to the southern Upolu and southeastern Savaii coastlines. This corresponds with the observed tsunami propagation pattern in which the main tsunami energy was directed northeast of the rupture source towards American Samoa [18]. The probable 1960 and/or 1868 distant tsunamis were identified only at Ma'asina (Figure 5b), which suggests that the Bay in which this site is located is conducive for capturing and preserving depositional signals associated with the far-field events. A similar, potential far-field event is identified at Ma'asina (Figures 4 and 5f).

The 1917 event appears to have left deposits only at Falealupo on west Savaii and along the southern shores of Upolu at Mulivai, Vaovao and Vaiula (Figure 5c). This is relatively consistent with the likely propagation of the 1917 tsunami in which the main energy beams were directed to the north and south of the epicentre [13], which was located approximately $150 \mathrm{~km}$ south-southwest of Falealupo (Figure 1). Less energy was directed eastward towards Upolu, which would have resulted in lower sediment depositional potential for this event in southern Upolu compared with the 2009 event.

The spatial distribution of the tsunami inferred between AD 1600-1800 (Figure 5d) appears to have left a more widespread footprint along the southern Upolu and Savaii compared with both the 2009 and 1917 events. This suggests a local source region and/or mechanism comparable to, and possibly larger than, both the 2009 and 1917 events and might represent a source located along the bend in the northern Tonga Trench between the 1917 and 2009 earthquake epicentres (Figure 1).

The $S$ anomaly which appears to be consistent amongst most sites around both Savaii and Upolu, including Fagali'i on the north Upolu (Figure 5e), are interpreted to represent a probable sea level high stand in this region [29,30], whereby the sites investigated may have been more subjected to coastal or marine conditions conducive for $\mathrm{S}$ accumulation, for example, as in [31].

The cores at Manono $(2.5 \mathrm{~m})$ and Lano $(1.5 \mathrm{~m})$ were longer than all other sites except Fagali'i, which enabled identification of older events (Figure $5 \mathrm{~g}, \mathrm{~h}$ ). The apparent tsunami signature at Lano for the interpreted AD 1100-1300 tsunami, compared with the 2009, 1917, and likely AD 1600-1800 events could represent a more localized event which might have affected east/northeast Savaii and west Upolu. However, in both cases shown in Figure 5f,h, it is difficult to make any definitive assumptions regarding their source origin due to the absence of comparable depositional data from the other sites.

Interestingly, no clear tsunami depositional signals were identified at Fagali'i on north Upolu, which could indicate that this area might not have experienced extreme tsunami inundation in the past 3000 years and, in particular, was associated with a northern Tonga Trench origin. On the other hand, the coarse data resolution of the Fagali'i profile also means that potential fine-scale tsunami signatures, which may exist at this site, are not adequately represented in the current datasets. 


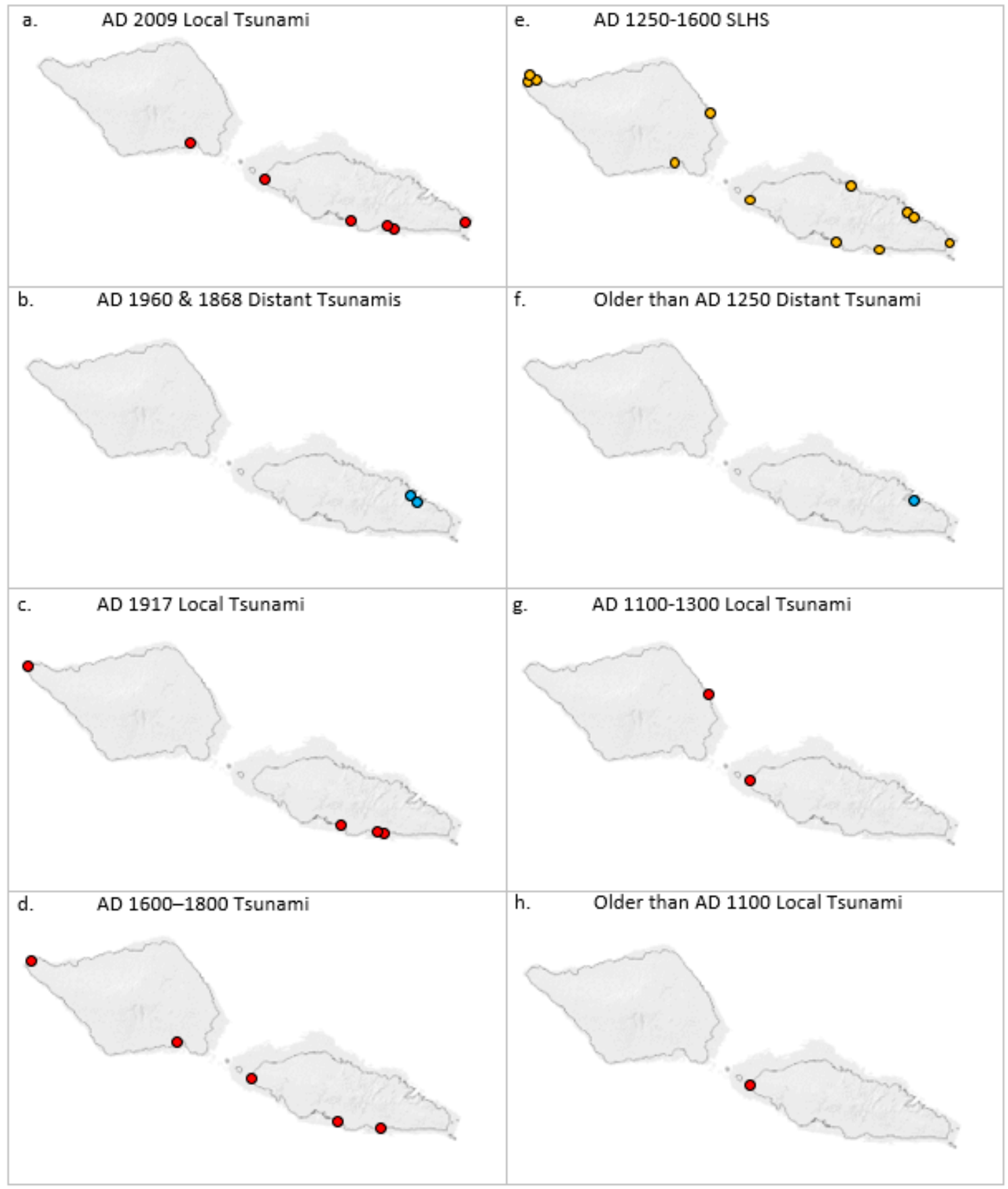

Figure 5. Distribution of deposits preserved for identified events shown in Figure 4. The distribution of the 2009 South Pacific Tsunami (SPT) deposits are shown in (a) and the distribution of the 1917 tsunami deposits are shown in (c). Events older than the 2009 and 1917 events which probably represent similar local source origins at the northern Tonga Trench are inferred in $(\mathbf{d}, \mathbf{g}, \mathbf{h})$. The interpreted seal-level high stand represented by the $\mathrm{S}$ anomaly consistent at most sites is inferred in (e). Signatures associated with far-field events appear to be captured at Ma'asina on the northeast coast of Upolu $(\mathbf{b}, \mathbf{f})$.

\section{Conclusions}

This study set out to reassess available tsunami depositional evidence in Samoa to provide a more representative long-term tsunami record in this region. Our findings suggest that, despite the relatively wide spatial coverage of available core and trench data from around these islands, inconsistencies in data resolution and/or available proxies between sites limits a consistent comparison 
of probable tsunami events. Nevertheless, the available datasets do enable a refined interpretation of likely tsunamis preserved in Samoan depositional records, with their spatial footprint providing an indication of the likely source origin/s.

Using the 2009 SPT deposits as an analogy for identifying older events, we identify the local 1917 historical tsunami deposits footprint and another probable event in AD 1600-1800. The more widespread distribution of the AD 1600-1800 deposits footprint in comparison to the 2009 and 1917 footprints indicate a similar source region at the northern Tonga Trench. Older probable events in AD 1100-1300 and older than AD 1100 could also be associated with this source region, suggesting that up to at least 3 predecessors to the 2009 tsunami occurred in the last millennium. However, the absence of comparable datasets from other sites limits a definitive association. On northeast Upolu, configurations of the bay and nearshore morphology at Ma'asina and Salimu provide conditions conducive for preserving deposits associated with far-field events such as the 1960 Valdivia tsunami. The absence of identified tsunami deposits at Fagali'i on north Upolu suggests that either this area has not experienced extreme tsunami inundation in the past 3000 years or that the coarse profile resolution of data at this site limits identification of fine-scale tsunami signals which could be present. Future studies of tsunami deposits in these islands should target higher and consistent profile resolutions, higher density of cores obtained from each investigated site to capture local inundation extents, and higher density of geochronological time-markers for each investigated area.

Author Contributions: Conceptualization, S.W. and G.P.; methodology, S.W., C.B., and G.P.; validation, S.W., A.T., C.B., and G.P.; formal analysis, A.T. and L.S.; investigation, S.W. and C.B.; resources, S.W., A.T., C.B., and L.S.; data curation, S.W. and L.S.; writing—original draft preparation, S.W.; writing—review and editing, S.W., A.T., C.B., L.S., and G.P.; visualization, S.W.; supervision, A.T. and L.S.; funding acquisition, S.W.; project administration, S.W. All authors have read and agreed to the published version of the manuscript.

Funding: This research was supported by New Zealand National Institute of Water \& Atmospheric Research (NIWA) Taihoro Nukurangi through Strategic Science Investment Funding grant numbers CARH2102 and PRAS2101, with the APC funded through grant number CARH2102.

Acknowledgments: The authors acknowledge and are grateful to the following colleagues for help provided towards earlier associated aspects of this research: Tim Davies, Catherine Chagué, James Goff, Kwok Fai Cheung, Thomas Wilson, Atun Zawadzki, Geraldine Jacobson, and the late Taulealeausumai Laavasa Malua. ${ }^{210} \mathrm{~Pb}$ and ${ }^{14} \mathrm{C}$ (OZP-samples) data were obtained in 2012 through an Australian Institute for Nuclear Science and Engineering grant, No. ALNGRA12119P; Patricia Gadd, Jack Goralewski, and Fiona Bertuch are thanked for their help with the ${ }^{210} \mathrm{~Pb}$ and ${ }^{14} \mathrm{C}$ dating undertaken at the Australian Nuclear Science and Technology Organisation. ${ }^{14} \mathrm{C}$ data (WK- samples) were obtained in 2012 through a NZ-Fulbright Programme Fellowship, IIE grantee No. 15101271; Fiona Petchey and Alan Hogg are acknowledged for providing ${ }^{14} \mathrm{C}$ data from the University of Waikato. Two anonymous reviewers are thanked for their helpful comments which improved the paper.

Conflicts of Interest: The authors declare no conflict of interest. The funders had no role in the design of the study; in the collection, analyses, or interpretation of data; in the writing of the manuscript; or in the decision to publish the results. 


\section{Appendix A}

Table A1. Radiocarbon data.

\begin{tabular}{|c|c|c|c|c|c|c|c|c|c|c|}
\hline Site & $\begin{array}{l}\text { Laboratory } \\
\text { No }^{1}\end{array}$ & Depth (cm) & $\begin{array}{c}\mathrm{CRA}^{2} \\
(\mathrm{yr} \mathrm{BP} \pm 1 \sigma)\end{array}$ & $\begin{array}{l}\delta 13 C \\
(\% o)\end{array}$ & $\begin{array}{l}95.4 \% \mathrm{CAR}^{3} \\
\text { (cal BP) }\end{array}$ & $\begin{array}{l}\text { Mean Age } \pm \\
2 \sigma(\text { cal BP) }\end{array}$ & $\begin{array}{l}95.4 \% \mathrm{CAR}^{3} \\
\text { (cal BC/AD) }\end{array}$ & $\begin{array}{l}\text { Mean Age } \pm 2 \sigma \\
\text { (cal BC/AD) }\end{array}$ & Material $^{4}$ & Context $^{4}$ \\
\hline \multirow[t]{2}{*}{ Satitoa } & Wk30079 & 81 & $150 \pm 95$ & $-28.0 \pm 0.2$ & 428-Modern & $173 \pm 220$ & AD 1523-1950+ & AD $1782 \pm 220$ & $\begin{array}{c}\text { Soil, } \\
\text { Organics }\end{array}$ & $\begin{array}{l}\text { Dark brown organic silty clay; sampled } \\
\text { near the trench base }\end{array}$ \\
\hline & OZP119 & 82 & $740 \pm 30$ & $0.0^{5}$ & $446-278$ & $359 \pm 90$ & AD 1509-1672 & AD $1591 \pm 90$ & Shell & $\begin{array}{l}\text { Unidentified shell in dark grey } \\
\text { calcareous sand; sampled near the } \\
\text { upper contact }\end{array}$ \\
\hline \multirow[t]{2}{*}{ Vaovai } & OZP117 & 23 & $720 \pm 25$ & $2.1 \pm 0.3$ & $425-270$ & $344 \pm 88$ & AD 1525-1680 & AD $1606 \pm 88$ & Shell & $\begin{array}{l}\text { Unidentified shell in light to dark yellow } \\
\text { sand; sampled near the upper contact }\end{array}$ \\
\hline & Wk30089 & 67 & $575 \pm 35$ & $3.1 \pm 0.2$ & 279->Modern & $171 \pm 130$ & AD 1671-1950+ & AD $1779 \pm 130$ & Shell & $\begin{array}{l}\text { Unidentified gastropod in organic rich } \\
\text { sand; approximately } 8 \mathrm{~cm} \text { from } \\
\text { upper contact }\end{array}$ \\
\hline \multirow[t]{3}{*}{ Mulivai } & OZP114 & 23 & $\begin{array}{l}(\mathrm{pMC} 109.08 \\
\quad \pm 0.38)\end{array}$ & $-27.8 \pm 0.1$ & $>$ Modern & $>$ Modern & $\begin{array}{l}\text { AD 1958; } \\
\text { 1999-2003 }\end{array}$ & $\mathrm{AD} 2000 \pm 12$ & $\begin{array}{c}\text { Soil, } \\
\text { Organics }\end{array}$ & $\begin{array}{l}\text { Dark brown organic soil; approximately } \\
5 \mathrm{~cm} \text { from base contact }\end{array}$ \\
\hline & OZP113 & 38 & $1125 \pm 35$ & $-25.9 \pm 0.3$ & 1173-958 & $1034 \pm 104$ & AD 777-992 & AD $916 \pm 104$ & $\begin{array}{c}\text { Soil, } \\
\text { Organics }\end{array}$ & $\begin{array}{l}\text { Thin olive brown soil layer sandwiched } \\
\text { between calcareous sands }\end{array}$ \\
\hline & Wk30084 & 93 & $530 \pm 95$ & $-25.1 \pm 0.2$ & $676-322$ & $549 \pm 164$ & AD 1275-1629 & AD $1401 \pm 164$ & Peat & $\begin{array}{l}\text { Dark brown fibrous peat; sampled from } \\
\text { the centre of the layer }\end{array}$ \\
\hline Fagali'I $^{6}$ & Wk30087 & 287 & $3110 \pm 50$ & $-27.8 \pm 0.2$ & $3446-3184$ & $3313 \pm 126$ & ВС 1497-1235 & BC $1364 \pm 126$ & Charcoal & $\begin{array}{l}\text { Single charcoal piece approximately } 5 \\
\mathrm{~cm} \text { a-axis in blackish peat; } \\
\text { approximately } 14 \mathrm{~cm} \text { from upper contact }\end{array}$ \\
\hline Falealupo & Wk30081 & 49 & $830 \pm 30$ & $-24.5 \pm 0.2$ & $790-687$ & $739 \pm 66$ & AD 1164-1264 & AD $1211 \pm 66$ & Peat & $\begin{array}{l}\text { Organic silty clay; sampled near the base } \\
\text { of the core }\end{array}$ \\
\hline \multirow[t]{2}{*}{ Lano } & Wk30083 & 139 & $800 \pm 30$ & $-27.8 \pm 0.2$ & $767-675$ & $716 \pm 48$ & AD 1184-1275 & $\mathrm{AD} 1234 \pm 48$ & $\begin{array}{c}\text { Plant } \\
\text { fragments }\end{array}$ & $\begin{array}{l}\text { Plant fragments in olive black silty sand; } \\
\text { near the base contact }\end{array}$ \\
\hline & Wk30082 & 149 & $1895 \pm 45$ & $-27.0 \pm 0.2$ & 1930-1716 & $1832 \pm 114$ & AD 20-234 & AD $118 \pm 114$ & Wood & Brown wood at the base of the core \\
\hline \multicolumn{11}{|c|}{$\begin{array}{l}{ }^{1} \text { Wk }=\text { University of Waikato, Radiocarbon Dating Laboratory (RDL); OZP }=\text { Australian Nuclear Science and Technology Organisation (ANSTO). }{ }^{2} \text { Conventional Radiocarbon Age (CRA) } \\
\text { calculated as per [32]; values have been rounded. }{ }^{3} \text { Calibrated Age Range (CAR) - Radiocarbon ages have been calibrated to the IntCal13 dataset [33] using OxCal v4.2.2 [34]. The use of } \\
\text { the northern hemisphere dataset for calibrating terrestrial materials from Samoa is proposed by [35] as these islands may be influenced by both southern and northern hemisphere air } \\
\text { masses. Shell samples were calibrated using the Marine13 dataset of [33] and } \Delta \mathrm{R}=28 \pm 26 \text {, as determined for Samoa by [36]. Sample OZP114 was calibrated using Bomb13 SH3 dataset } \\
{[37] .{ }^{4} \text { Refer to [21] for descriptions of the respective core strata. Core and trench sampling was conducted in July and August } 2010 .{ }^{5} \delta^{13} \mathrm{C} \text { is an assumed value; a measured value was not }} \\
\text { available. }{ }^{6} \text { Sample Wk30087 is a taxonomically unidentified charcoal specimen. It could be subject to the effects of in-built age, meaning the true calendar age of the sample could be few } \\
\text { hundred years younger [38,39]. }\end{array}$} \\
\hline
\end{tabular}


Table A2. Pb Radiochemistry data for the Falealupo site cored in 2010

\begin{tabular}{|c|c|c|c|c|c|c|c|c|c|c|}
\hline Site & ANSTO ID & Depth $(\mathrm{cm})$ & $\begin{array}{l}\text { Dry Bulk } \\
\text { Density } \\
\left(\mathrm{g} / \mathrm{cm}^{3}\right)\end{array}$ & $\begin{array}{l}\text { Cumulative } \\
\text { Dry Mass } \\
\left(\mathrm{g} / \mathrm{cm}^{2}\right)\end{array}$ & $\begin{array}{c}\text { Total }{ }^{210} \mathrm{~Pb} \\
(\mathrm{~Bq} / \mathrm{kg})\end{array}$ & $\begin{array}{c}\text { Supported } \\
210 \mathrm{~Pb} \\
(\mathrm{~Bq} / \mathrm{kg})\end{array}$ & $\begin{array}{c}\text { Unsupported } \\
{ }_{210} \mathrm{~Pb} \\
(\mathrm{~Bq} / \mathrm{kg})^{1}\end{array}$ & $\begin{array}{c}\text { Calculated } \\
\text { CIC Ages } \\
\text { (Years) }^{2}\end{array}$ & $\begin{array}{c}\text { Calculated } \\
\text { CRS Ages } \\
\text { (Years) }^{3}\end{array}$ & $\begin{array}{l}\text { CRS Model Mass } \\
\text { Accumulation } \\
\text { Rates }\left(\mathrm{g} / \mathrm{cm}^{2} / \text { Year) }\right.\end{array}$ \\
\hline \multirow[t]{9}{*}{ Falealupo } & N574 & $0-1$ & 0.98 & $0.5 \pm 0.5$ & $20.9 \pm 0.8$ & $0.4 \pm 0.1$ & $21.1 \pm 0.9$ & $1 \pm 1$ & $1 \pm 1$ & $0.52 \pm 0.03$ \\
\hline & N575 & $1-2$ & 1.14 & $1.5 \pm 0.5$ & $21.1 \pm 0.9$ & $0.4 \pm 0.1$ & $21.3 \pm 0.9$ & $3 \pm 1$ & $3 \pm 2$ & $0.48 \pm 0.03$ \\
\hline & N576 & $2-3$ & 0.78 & $2.5 \pm 0.5$ & $18.4 \pm 0.7$ & $0.3 \pm 0.1$ & $18.6 \pm 0.8$ & $5 \pm 1$ & $5 \pm 2$ & $0.52 \pm 0.03$ \\
\hline & N638 & $8-9$ & 1.30 & $8.8 \pm 0.5$ & $15.4 \pm 0.6$ & $0.2 \pm 0.1$ & $15.8 \pm 0.7$ & $16 \pm 3$ & $19 \pm 4$ & $0.40 \pm 0.03$ \\
\hline & N577 & $9-10$ & 1.03 & $9.9 \pm 0.5$ & $12.9 \pm 0.6$ & $0.4 \pm 0.1$ & $12.8 \pm 0.6$ & $18 \pm 4$ & $21 \pm 5$ & $0.45 \pm 0.04$ \\
\hline & N578 & $15-16$ & 0.78 & $15.3 \pm 0.5$ & $13.9 \pm 0.6$ & $1.1 \pm 0.1$ & $13.2 \pm 0.7$ & $28 \pm 6$ & $36 \pm 6$ & $0.28 \pm 0.03$ \\
\hline & N639 & $18-19$ & 0.60 & $17.4 \pm 0.5$ & $14.7 \pm 0.6$ & $2.9 \pm 0.3$ & $12.2 \pm 0.7$ & $32 \pm 7$ & $45 \pm 7$ & $0.23 \pm 0.03$ \\
\hline & N640 & $22-24$ & 0.75 & $20.5 \pm 0.9$ & $11.8 \pm 0.5$ & $2.9 \pm 0.3$ & $9.2 \pm 0.6$ & $38 \pm 8$ & $59 \pm 8$ & $0.20 \pm 0.03$ \\
\hline & N579 & $28-30$ & 0.59 & $24.5 \pm 0.8$ & $3.2 \pm 0.2$ & $0.0 \pm 0.0$ & $3.3 \pm 0.2$ & $45 \pm 9$ & $75 \pm 9$ & $0.32 \pm 0.06$ \\
\hline
\end{tabular}

${ }^{1}$ Decay corrected to 11 May 2011. Count dates for N574, N575, N576, N577, N578, and N579= 17 May 2012. Count dates for N638, N639, and N640 = 11 July 2012. ${ }^{2}$ CIC (constant initial ${ }^{210} \mathrm{~Pb}$ concentration) model mass accumulation rate $=0.54 \pm 0.1 \mathrm{~g} / \mathrm{cm}^{2} / \mathrm{y} ; \mathrm{r}^{2}=0.775253 .{ }^{3} \mathrm{CRS}$ (constant rate of ${ }^{210} \mathrm{~Pb}$ supply) ages for this site are reported in the text. All ages are reported at 2 sigma.

Table A3. ${ }^{210} \mathrm{~Pb}$ radiochemistry data for the Ma'asina site cored in 2010.

\begin{tabular}{|c|c|c|c|c|c|c|c|c|c|c|}
\hline Site & ANSTO ID & Depth $(\mathrm{cm})$ & $\begin{array}{c}\text { Dry Bulk } \\
\text { Density } \\
\left(\mathrm{g} / \mathrm{cm}^{3}\right)\end{array}$ & $\begin{array}{l}\text { Cumulative } \\
\text { Dry Mass } \\
\left(\mathrm{g} / \mathrm{cm}^{2}\right)\end{array}$ & $\begin{array}{c}\text { Total }{ }^{210} \mathrm{~Pb} \\
(\mathrm{~Bq} / \mathrm{kg})\end{array}$ & $\begin{array}{c}\text { Supported } \\
{ }_{210} \mathrm{~Pb} \\
(\mathrm{~Bq} / \mathrm{kg})\end{array}$ & $\begin{array}{c}\text { Unsupported } \\
{ }_{210} \mathrm{~Pb} \\
(\mathrm{~Bq} / \mathrm{kg})^{1}\end{array}$ & $\begin{array}{l}\text { Calculated } \\
\text { CIC Ages } \\
\text { (Years) }^{2}\end{array}$ & $\begin{array}{c}\text { Calculated } \\
\text { CRS Ages } \\
\text { (Years) }\end{array}$ & $\begin{array}{l}\text { CRS Model Mass } \\
\text { Accumulation } \\
\text { Rates }\left(\mathrm{g} / \mathrm{cm}^{2} / \text { Year }\right)\end{array}$ \\
\hline \multirow[t]{5}{*}{ Ma'asina } & N580 & $0.0-1.5$ & 1.20 & $0.9 \pm 0.9$ & $12.9 \pm 0.6$ & $3.1 \pm 0.3$ & $9.9 \pm 0.7$ & $3 \pm 3$ & $3 \pm 1$ & $0.32 \pm 0.03$ \\
\hline & N581 & $3.0-4.0$ & 1.69 & $4.8 \pm 0.7$ & $10.6 \pm 0.5$ & $3.2 \pm 0.3$ & $7.4 \pm 0.6$ & $14 \pm 3$ & $16 \pm 1$ & $0.29 \pm 0.04$ \\
\hline & N583 & $6.0-7.5$ & 2.16 & $11.1 \pm 1.2$ & $8.2 \pm 0.4$ & $3.1 \pm 0.3$ & $5.1 \pm 0.5$ & $33 \pm 6$ & $43 \pm 4$ & $0.18 \pm 0.03$ \\
\hline & N582 & $10.0-11.0$ & 1.37 & $17.7 \pm 0.8$ & $4.8 \pm 0.3$ & $2.8 \pm 0.3$ & $2.0 \pm 0.4$ & $53 \pm 8$ & $86 \pm 11$ & $0.12 \pm 0.04$ \\
\hline & N585 & $16.0-17.5$ & 1.93 & $28.0 \pm 1.3$ & $9.3 \pm 0.5$ & $3.7 \pm 0.3$ & $5.6 \pm 0.6$ & No Result & No Result & No Result \\
\hline
\end{tabular}

${ }^{1}$ Decay corrected to 11 May 2012. Count date $=17$ May 2012. ${ }^{2}$ CIC model mass accumulation rate $=0.334 \pm 0.05 \mathrm{~g} / \mathrm{cm}^{2} / \mathrm{y} ; \mathrm{r}^{2}=0.9554$. CIC ages for this site are reported in the text. All ages are reported at 2 sigma. Unsupported ${ }^{210} \mathrm{~Pb}$ data from samples $\mathrm{N} 585$ and N584 were not included in the ${ }^{210} \mathrm{~Pb}$ dating calculations. 


\section{References}

1. Dawson, A.; Stewart, I. Tsunami Geoscience. Prog. Phys. Geogr. 2007, 31, 575-590. [CrossRef]

2. Goto, K.; Chagué-Goff, C.; Fujino, S.; Goff, J.; Jaffe, B.; Nishimura, Y.; Richmond, B.; Suguwara, D.; Szczuciński, W.; Tappin, D.R.; et al. New insights into tsunami risk from the 2011 Tohoku-oki event. Mar. Geol. 2011, 290, 46-50. [CrossRef]

3. Goff, J.; Chagué-Goff, C.; Nichol, S.L.; Jaffe, B.; Dominey-Howes, D. Progress in palaeotsunami research. Sediment. Geol. 2012, 243-244, 70-88. [CrossRef]

4. Nott, J.; Green, C.; Townsend, I.; Callaghan, J. The world record cyclone surge and the most intense southern hemisphere tropical cyclone. Bull. Am. Meteorol. Soc. 2014, 95, 757-765. [CrossRef]

5. Morton, R.A.; Gelfenbaum, G.; Jaffe, B.E. Physical criteria for distinguishing sandy tsunami and cyclone deposits using modern examples. Sediment. Geol. 2007, 200, 184-207. [CrossRef]

6. Komatsubara, J.; Fujiwara, O.; Takada, K.; Sawai, Y.; Aung, T.T.; Kamataki, T. Historical tsunamis and cyclones recorded in a coastal lowland, Shizuoka Prefecture, along the Pacific Coast of Japan. Sedimentology 2008, 55, 1703-1716. [CrossRef]

7. Chagué-Goff, C. Chemical signatures of palaeotsunamis: A forgotten proxy? Mar. Geol. 2010, $271,67-71$. [CrossRef]

8. Chagué-Goff, C.; Szczuciński, W.; Shinozaki, T. Applications of geochemistry in tsunami research: A review. Earth-Sci. 2017, 165, 203-244.

9. Chagué, C. Applications of Geochemical Proxies in Paleotsunami Research; Elsevier BV: Amsterdam, The Netherlands, 2020; pp. 381-401.

10. Nanayama, F.; Shigeno, K.; Satake, K.; Shimokawa, K.; Koitabashi, S.; Miyasaka, S.; Ishii, M. Sedimentary differences between the 1993 Hokkaido-nansei-oki tsunami and the 1959 Miyakojima typhoon at Taisei, southwestern Hokkaido, northern Japan. Sediment. Geol. 2000, 135, 255-264. [CrossRef]

11. Kortekaas, S.; Dawson, A.G. Distinguishing tsunami and cyclone deposits: An example from Martinhal, SW Portugal. Sediment. Geol. 2007, 200, 208-221. [CrossRef]

12. Phantuwongraj, S.; Choowong, M. Tsunamis versus cyclone deposits from Thailand. Nat. Hazards 2012, 63, 31-50. [CrossRef]

13. Okal, E.; Borrero, J.; Chagué-Goff, C. Tsunamigenic predecessors to the 2009 Samoa earthquake. Earth-Sci. Rev. 2011, 107, 127-140. [CrossRef]

14. Chagué-Goff, C.; Schneider, J.-L.; Goff, J.; Dominey-Howes, D.; Strotz, L. Expanding the proxy toolkit to help identify past events: Lessons from the 2004 Indian Ocean Tsunami and the 2009 South Pacific Tsunami. Earth-Sci. Rev. 2011, 107, 107-122.

15. Richmond, B.M.; Buckley, M.; Etienne, S.; Chagué-Goff, C.; Clark, K.; Goff, J.; Dominey-Howes, D.; Strotz, L. Deposits, flow characteristics, and landscape change resulting from the September 2009 South Pacific tsunami in the Samoan islands. Earth-Sci. Rev. 2011, 107, 38-51. [CrossRef]

16. Beavan, J.; Wang, X.; Holden, C.; Wilson, K.; Power, W.; Prasetya, G.; Bevis, M.; Kautoke, R. Near-simultaneous great earthquakes at Tongan megathrust and outer rise in September 2009. Nat. Cell Biol. 2010, 466, 959-963. [CrossRef]

17. Lay, T.; Ammon, C.J.; Kanamori, H.; Rivera, L.; Koper, K.D. The 2009 Samoa-Tonga great earthquake triggered doublet. Nature 2010, 466, 964-968. [CrossRef]

18. Roeber, V.; Yamazaki, Y.; Cheung, K.F. Resonance and impact of the 2009 Samoa tsunami arounnd Tutuila. Geophys. Res. Lett. 2010, 37, 8. [CrossRef]

19. Williams, S.; Leavasa, A.M. Exploring the status of tsunami early warning systems in Samoa. In Proceedings of the Samoa National Environment Forum 2005, Apia, Samoa, 25 November 2005; pp. 52-58.

20. Williams, S.; Goff, J.; Prasetya, G.; Cheung, K.F.; Chagué-Goff, C.; Davies, T.; Wilson, T. Characterising diagnostic proxies for identifying palaeotsunamis in a tropical climatic regime, Samoan Islands. In Proceedings of the MTS/IEEE OCEANS 2011 Kona Conference, Kailua Kona, HI, USA, 19-22 September 2011; p. 10.

21. Williams, S.; Goff, J.; Ah Kau, J.; Sale, F.; Chagué-Goff, C.; Davies, T. Geological Investigation of Palaeotsunamis in the Samoan Islands: Interim Report and Research Directions. Sci. Tsunami Hazards 2013, 32, 156-175. 
22. Williams, S. Tsunami Elemental Signatures in the Samoan Islands: A Case Study. In Applied Geochemistry with Case Studies on Geological Formations, Exploration Techniques and Environmental Issues; Intech Open: London, UK, 2019. [CrossRef]

23. FUGRO. Report of Survey: Airborne Lidar Bathymetric and Topographic Survey of Samoa; Contract: ECRCR-LIB 2.1, Fugro LADS Document Reference No: TLCS00.047.008, Issue No: 1.00; Fugro LADS Corporation Pty Ltd.: Kidman Park, SA, Australia, 2015.

24. Dinis, P.; Castilho, A. Integrating sieving and laser data to obtain bulk grain-size distributions. J. Sediment. Res. 2012, 82, 747-754. [CrossRef]

25. Appleby, P.G. Chronostratigraphic techniques in recent sediments. In Tracking Environmental Change Using Lake Sediments, Volume 1: Basin Analysis, Coring and Chronological Techniques; Last, W.M., Smol, J.P., Eds.; Kluwer Academic Publishers: Dordrecht, The Netherlands, 2001; pp. 171-203.

26. Williams, S. Tsunami Hazard, Samoan Islands: Palaeotsunami Investigation, Numerical Modeling and Risk Implications. Ph.D. Thesis, Department of Geological Sciences, University of Canterbury, Christchurch, New Zealand, 30 April 2014.

27. Gustafsson, J.P. Vanadium geochemistry in the biogeosphere-speciation, solid-solution interactions, and ecotoxicity. Appl. Geochem. 2019, 102,1-25. [CrossRef]

28. Pararas-Carayannis, G.; Dong, B. Catalog of Tsunamis in the Samoan Islands; International Tsunami Information Center: Honolulu, HI, USA, 1980.

29. Grinsted, A.; Moore, J.C.; Jevrejeva, S. Reconstructing sea level from paleo and projected temperatures 200 to 2100 AD. Clim. Dyn. 2010, 34, 461-472. [CrossRef]

30. Cochrane, E.E.; Kane, H.; Fletcher, C.; Horrocks, M.; Mills, J.; Barbee, M.E.; Morrison, A.; Tautunu, M.M. Lack of suitable coastal plains likely influenced Lapita ( 2800 cal. BP) settlement of Sāmoa: Evidence from south-eastern 'Upolu. Holocene 2015, 26, 126-135. [CrossRef]

31. Findlay, A.; Pellerina, A.; Laufera, K.; Jørgensen, B.B. Quantification of sulphide oxidation rates in marine sediment. Geochim. Cosmochim. Acta 2020, 280, 441-452. [CrossRef]

32. Stuiver, M.; Polach, H.A. Discussion Reporting of 14C Data. Radiocarbon 1977, 19, 355-363. [CrossRef]

33. Reimer, P.; Bard, E.; Bayliss, A.; Beck, J.; Blackwell, P.; Ramsey, C.; Buck, C.; Cheng, H.; Edwards, R.; Friedrich, M.; et al. IntCal13 and Marine13 Radiocarbon Age Calibration Curves 0-50,000 Years cal BP. Radiocarbon 2013, 55, 1869-1887. [CrossRef]

34. Bronk-Ramsey, C. OxCal Program, Version 4.2; Radiocarbon Accelerator Unit; University of Oxford: Oxford, UK, 2013.

35. Petchey, F.; Spriggs, M.; Leach, F.; Seed, M.; Sand, C.; Pietrusewsky, M.; Anderson, K. Testing the human factor: Radiocarbon dating the first peoples of the South Pacific. J. Archaeol. Sci. 2011, 38, 29-44. [CrossRef]

36. Petchey, F.; Anderson, A.; Zondervan, A.; Ulm, S.; Hogg, A. New marine $\Delta \mathrm{R}$ values for the South Pacific subtropical gyre region. Radiocarbon 2008, 50, 373-397. [CrossRef]

37. Hua, Q.; Barbetti, M.; Rakowski, A. Atmospheric Radiocarbon for the Period 1950-2010. Radiocarbon 2013, 55, 2059-2072. [CrossRef]

38. Allen, M.S.; Wallace, R. New evidence from the East Polynesian gateway: Substantive and methodological results from Aitutaki, southern Cook Islands. Radiocarbon 2007, 9, 1-17. [CrossRef]

39. Williams, S.; Goff, J.; Davies, T. Deep Charcoal Found at Fagali'i Village, Upolu Island, Samoa: Natural or Anthropogenic in Origin? J. Isl. Coast. Archaeol. 2014, 9, 425-429. [CrossRef]

Publisher's Note: MDPI stays neutral with regard to jurisdictional claims in published maps and institutional affiliations.

(C) 2020 by the authors. Licensee MDPI, Basel, Switzerland. This article is an open access article distributed under the terms and conditions of the Creative Commons Attribution (CC BY) license (http://creativecommons.org/licenses/by/4.0/). 